\title{
DEVELOPING PRIMARY SCHOOL PUPILS' TECHNICAL IMAGINATION WITH THE SUPPORT OF VIRTUAL 3D MODELS
}

Peter KUNA, Univerzita Konštantína Filozofa v Nitre, Slovenská republika Silvia KUNOVÁ, Univerzita Konštantína Filozofa v Nitre, Slovenská republika Tomáš KOZÍK, Univerzita Konštantína Filozofa v Nitre, Slovenská republika

Přijato: 30. 1. 2017 / Akceptováno: 23. 6. 2017

Typ článku: Výskumná štúdia

DOI: $10.5507 /$ jtie.2017.012

Abstract: Research confirmed the positive impact of the use of virtual 3D models on the development of the spatial imagination of pupils in learning. The pedagogical experiment showed that the pupils using virtual models in the achieved better results in the overall assessment compared to pupils who used real models in the classroom. The Geomagic Design software and the Adobe Acrobat Reader presentation tool are the appropriate tools for creating $3 D$ models and presenting them in the classroom. Their use in the research program showed that respondents - the elementary school pupils nor the teachers had no problem working with them.

The application of virtual reality in teaching technical and natural science subjects is an appropriate means to support and develop the creative predispositions of pupils.

Key words: Technical education, imagination, virtual 3D model, virtual reality

\section{ROZVÍJANIE TECHNICKEJ PREDSTAVIVOSTI ŽIAKOV ZŠ S PODPOROU VIRTUÁLNYCH 3D MODELOV}

Abstrakt: Výskum potvrdil pozitívny vplyv použitia virtuálnych $3 D$ modelov vo výučbe na rozvoj priestorovej predstavivosti žiakov. V pedagogickom experimente bolo preukázané, že žiaci vyučovaní s použitím virtuálnych modelov v celkovom hodnoteni dosiahli lepšie výsledky v porovnani so žiakmi, ktorí vo vyučovaní použivali reálne modely.

Softvérový nástroj Geomagic Design a prezentačný nástroj Adobe Acrobat Reader sú vhodnými nástrojmi na tvorbu $3 D$ modelov a ich prezentáciu pri výučbe. Ich použitie vo výskumnom programe ukázalo, že respondenti, žiaci základných škôl, ale ani učitelia, nemali žiadny problém s nimi pracovat'.

Aplikovanie systému virtuálnej reality vo výučbe technických a prírodovedných predmetov je vhodným prostriedkom na podporu a rozvoj kreatívnych predispozícii žiakov.

Kl'účové slová: Technické vzdelávanie, predstavivost', virtuálny 3D model, virtuálna realita

*Autor pro korespondenci: peter.kuna@ukf.sk 


\section{Úvod}

Priestorová predstavivost' reprezentuje základnú schopnost' každého úspešného pracovníka pôsobiaceho voblasti prírodných a technických vied. Prvotné impulzy vznikajúceho technického diela alebo výskumu prírodného javu vznikajú u výskumníka alebo konštruktéra $\mathrm{v}$ jeho myšlienkovej imaginárnej podobe, teda predstave, ktorá sa neskôr rozvinie do návrhu alebo vytvorenia užitočného diela pre človeka.

Platí to aj v prípade vzájomnej odbornej komunikácie pracovníkov vedy a techniky, ktorá je uskutočňovaná prostredníctvom technických výkresov, či matematických alebo chemických vzorcov. Ich správne vnímanie a chápanie je založené na dobre rozvinutej predstavivosti jednotlivcov. V technických odboroch, úspešnost' technických riešení, závisí od dispozície konštruktéra, odborníka komplexne vnímat' a chápat' technické a prírodovedné súvislostí, vediet' ich vyjadrit' technickými prostriedkami, t.j. mat' rozvinutú priestorovú predstavivost'.

Výučba technických a prírodovedných predmetov je náročná na materiálne zabezpečenie. Potrebné didaktické prostriedky a vybavenie laboratórií je vel'mi nákladné. Vedenia škôl, bez ohl'adu na typ školy, musia často vynaložit' enormné úsilie na zabezpečenie potrebnej materiálnej podpory výučby. Čiastkovým riešením tohto, na prvý pohl'ad vel'mi t'ažko riešitel'ného stavu, môže byt' aplikovanie systémov virtuálnej reality vo vzdelávaní. To znamená, nahradenie rôznych reálnych predmetov a didaktických pomôcok používaných žiakmi virtuálnymi pomôckami a virtuálnymi 3D objektmi (modelmi). Ekonomickú výhodnost' použitia virtuálnych modelov vo výučbe nemožno spochybnit'. Pre rozširovanie 3D aplikácií v praxi je však dôležité a nevyhnutné výskumne preukázat', že použitie virtuálnych modelov vo výučbe vedie k porovnatel'ným vzdelávacím výsledkom, ak nie lepším, ako je tomu pri používaní reálnych modelov. Preukázanie tohto predpokladu je ciel'om príspevku.

\section{Technická predstavivost'}

Psychológia definuje predstavivost' ako schopnost' človeka vytvárat' v mysli kópie (obrazy) vnemov aj v takom prípade, ked' nie je prítomný skutočný zmyslový podnet. Potom predstavivost' (Kelnarová, J. - Matějková, E. 2010) je psychický dej, ktorý vedie k vzniku pamätových predstáv, ktoré sú mentálnymi prezentáciami predchádzajúceho vnemu. Predstavy majú tendenciu spolu asociovat' (prepojovat') a pri ich spracovávaní jednotlivcom sa často u neho vytvorí aktuálna predstava, ale i d'alšie, ktoré sú s tou pôvodnou prepojené.

Podl'a Uherčíkovej (1999) predstavivost' v bežnom živote treba chápat' ako schopnost' vytvárat' a vybavovat' si v mysli predstavy. Predstava je potom obraz vytvorený v mysli na základe predchádzajúceho vnemu rozumovou činnost'ou alebo na základe skúseností. Pedagogika chápe predstavivost' skôr ako produkt intelektuálnej aktivity jednotlivca žiaka, s ciel'om o jej pozitívne ovplyvňovanie výchovno-vzdelávacím procesom. Bezprostredné dojmy človeka taktiež rozvíjajú a vplývajú na jeho predstavivost'. Predovšetkým sa u neho zdokonal'uje rekonštrukčná predstavivost', ktorá je spojená s predstavou skôr vnímaného materiálu, predmetu alebo javu. Predstavy žiakov pritom nestrácajú na živosti, jasnosti a konkrétnosti, ale sú stále viac realistickejšie, stále vernejšie odrážajú obsah učebných predmetov, prečítaných kníh, prestávajú byt' nesúvislé. Taktiež sa rozvíja u nich aj tvorivá predstavivost' vo forme vytvárania nových obrazov alebo pretváraním dojmov z minulej skúsenosti (Iljinová 1972). 
Schopnost' človeka vytvorit' si predstavu o priestorovom usporiadaní sveta/objektov a túto predstavu využívat' pri práci a v tvorivých aktivitách, nazývame priestorovou predstavivost'ou (Atkinson 2003). Je to nielen videnie alebo vnímanie priestoru, ale je to schopnost' tento priestor si aj uvedomit' (Peterčaj a Repáš, 1985). Priestorovú predstavivost' ako schopnost' je možné neustále rozvíjat' a zdokonal'ovat'. Na to, aby deti začali vnímat priestor je nutné, aby získavali konkrétne predstavy o predmetoch a javoch okolitého sveta (Molnár 2004).

Pedagógovia prípravou a zadávaním vhodných úloh a cvičení, napomáhajú svojim žiakom/študentom rozvíjat' priestorovú predstavivost'. Zadávané úlohy a cvičenia musia byt' primerané veku, možnostiam a schopnostiam žiakov. Činitel', ktorý môže najviac ovplyvnit' utváranie priestorovej predstavivosti žiaka, je vlastná činnost' žiaka, do ktorej je zapojených čo najviac zmyslov. Podla psychológov sú dve obdobia vo vývoji diet’ata, ktoré sú pre rozvoj priestorovej predstavivosti najvhodnejšie. Prvé obdobie je v 5. a 6. roku života a druhé obdobie je medzi 10. až 14. rokom. U žiakov staršieho školského veku sa po prvý krát objavuje aj tzv. tvorivá fantázia, ktorú uplatňuje pri rôznych činnostiach umelecká tvorba, hra, konštruovanie a pod. (Kuric 1992).

Šarounová (1988) definuje priestorovú predstavivost' ako súbor čiastkových schopností, ktoré sa týkajú predstáv o priestore, tvaroch a vzájomných vztahoch medzi telesami, medzi predmetmi a pozorovatel'om a telom samotného pozorovatela.

S rozvojom priestorovej predstavivosti je spojená vizuálna pamät' a logické myslenie. Prirodzeným spôsobom sa táto schopnost' rozvíja $\mathrm{v}$ detstve pri rôznych hrách, manipuláciou s hračkami, postupne od jednoduchších až $\mathrm{k}$ zložitejším modelom alebo dokonca tvorby vlastných návrhov. Priestorová predstavivost' je podmienená nielen zážitkovými skúsenost’ami diet’ata, ale aj uvedomovaním si priestorových vzt’ahov. $S$ rozvíjaním predstavivosti diet'at’a treba systematicky začat' pracovat' už v predškolskej výchove. S priestorovou predstavivost'ou sa človek nenarodí, ale musí ju postupne rozvíjat', obohacovat' a zdokonal'ovat' (Jirotková, 1990).

V technickom vzdelávaní priestorovej predstavivosti prislúcha dôležitá úlohu. Ide o vytváranie názorného obrazu predmetov a javov, ktoré $\mathrm{v}$ danom momente nie sú jednotlivcom vnímané a zväčša ani v minulosti neboli v takejto podobe vnímané. Aby mohli byt' vlastné predstavy jednotlivca, čo najvernejšie zachytené a d'alej rozvíjané, pomáha si vytváraním nákresov, náčrtov, schémami a pod. (Kožuchová, 1995, s.136).

Tomková (2013, s.38) publikované názory na technickú predstavivost' zjednotila do dvoch definícií:

a) Technickú predstavivost' môžeme chápat' ako schopnost' jednotlivca predstavit' si na základe predchádzajúcich vnemov, úplne nový, neexistujúci, reálny objekt, proces alebo jav, $\mathrm{v}$ jeho konečnej podobe a vo vzájomnej interakcií s prostredím, ktoré ho obklopuje.

b) Technická predstavivost' je schopnost' jednotlivca tvorit' nové reálne obrazy predmetov a javov na základe obrazov predmetov a javov, ktoré v minulosti pôsobili na naše vnemy, s ciel'om zlepšenia ich vlastností, funkcií alebo ulahčenia manipulácie s nimi (Tomková, 2013, s.38).

S technickou predstavivost'ou úzko súvisí technická tvorivost'. Nemecký pedagóg W. Hande (1985) uvádza základné požiadavky, ktoré sú potrebné pre rozvoj technickej tvorivosti žiakov: 
- Žiaci pri rozvíjaní technickej tvorivej činnosti majú využívat' vedomosti z technických, ekonomických a prírodných vied.

- Majú sa oboznámit' s heuristickými metódami i s rozličnými technickými činnost’ami za účelom vyriešenia technických problémov.

- $\quad$ Na technickú tvorivú činnost' musia byt' vhodne motivovaní.

- Z Žiaci majú riešit' problémy, ktoré sú primerané ich schopnostiam.

Fajnorová (2012) pomocou testov zist'ovala úroveň grafickej zručnosti žiakov základných škôl v Slovenskej a Českej republike. Okrem zistenia, že grafické zručnosti žiakov nie sú na požadovanej úrovni zistila, že žiaci navštevujúci školu s posilnením predmetov - matematika, fyzika, geografia a technika mali lepšie výsledky ako žiaci, ktorí navštevujú školu, kde takéto predmety vyučujú nekvalifikovaní učitelia, alebo kde sa predmet technika nevyučuje vôbec. Pre prax odporúča rozvíjat' grafickú gramotnost' žiakov prostredníctvom predmetu technika na základných školách a aj osemročných gymnáziách.

Molnár a Tláskal (2012) vychádzajúc z výsledkov dlhodobého výskumu priestorovej predstavivosti u žiakov základných a stredných škôl konštatujú dlhodobo znižujúcu sa úroveň priestorovej predstavivosti u žiakov. Príčiny tohto stavu vidia $\mathrm{v}$ nedocenení významu úlohy dobre vyvinutej priestorovej predstavivosti žiakov pre ich d’alšie štúdium a prax, ale aj v nedostatočnej časovej dotácii zameranej na rozvoj priestorovej orientácie žiakov vo vzdelávacom obsahu na základných školách, $\mathrm{v}$ nedostatočnej úrovni pripravenosti učitel'ov, vo vzt’ahu aplikovania výučby zameranej na rozvoj priestorovej predstavivosti žiakov a nerešpektovanie pedagogicko-psychologických zásad.

Z hl'adiska psychomotorického vývinu diet'ata Repáš (Hejný 1990) konštatuje existenciu istých časových období, ktoré sú zvlášst priaznivé pre rozvoj schopností priestorového videnia. Ked' sa tieto obdobia premeškajú, stráca diet’a možnost' rozvinút' svoje schopnosti na úroveň, ktorú mu predurčili jeho genetické dispozície.“

Beisetzer a Vrškový $(2008$, s.106) vidia priestor na možné realizovanie zámerného rozvoja priestorovej predstavivosti žiakov $\mathrm{v}$ rámci ich technického vzdelávania na základnej škole. Je pritom potrebné využívat' rôzne pomôcky zamerané na trénovanie tejto schopnosti (stavebnice, hlavolamy, logické hry a pod.) alebo riešit' úlohy, ktoré sú orientované na vizualizáciu a chápanie priestorových vzt’ahov (riešenie vyžaduje schopnost' transformovat' plošné videnia na priestorové, resp. priestorové na plošné v zmysle dohodnutých pravidiel zvolenej metódy premietania).

Úspešnost' riešenia geometrických úloh je úzko spojená súrovňou priestorovej orientácie žiaka/študenta. E. Pavelová (2003, s.78) poukazuje na vedomosti študentov z geometrie, ktoré sú z roka na rok slabšie a formálnejšie. Predpokladá, že tieto nedostatky študentov sú spôsobené v dôsledku zniženia hodinovej dotácie výučby stereometrie na ZŠ s SŠ a sústredenia pozornosti žiakov na získavanie formálnych vedomosti. $\mathrm{Na}$ eliminovanie uvedeného stavu, autorka odporúča na ZŠ používat' vo výučbe modely telies vo väčšej miere ako je tomu doteraz, nechat' žiakom čas na pochopenie daného učiva, rozvíjat' priestorovú predstavivost' a vhodnou motiváciou ukázat', kde sa využijú získané vedomosti v praktickom živote.

Z uskutočneného prehl'adu odborných prác a výsledkov výskumu slovenských a českých autorov k problematike rozvíjania priestorovej orientácie žiakov sme dospeli k záveru, že skúmaniu vplyvu virtuálneho 3D prostredia na rozvoj priestorovej/technickej 
predstavivosti nie je venovaná zo strany pedagogického výskumu dostatočná pozornost', ako na Slovensku tak aj v Čechách, a to aj napriek tomu, že virtuálny svet, svet počítačových hier sa stáva dôležitým výchovnovzdelávacom činitel’om mladej generácie.

\section{Experimentálne riešenie - opodstatnenost' uskutočnenia experimentu}

Výsledky výskumu uskutočneného na Slovensku v rokoch 2008/2009 na vzorke 3000 detí vo veku od 6 do 17 rokov ukázali, že až 64/71 (vidiek/mesto) percent detí sa venuje denne v priemere 1,4 / 1,85 hodiny hraniu počítačových hier (Vitáriušová E. a kol., 2009). Podla tohto výskumu dnešní žiaci trávia významnú čast' svojho vol'ného času pri počítači, najmä pri hraní počítačových hier. Interaktívne virtuálne 3D prostredie sa tak stáva významným výchovno-vzdelávacím prostriedkom, ktorý nemožno $\mathrm{z}$ pedagogickopsychologického pohl'adu prehliadat'. Predpokladáme, že počítačová virtuálna realita hier vo vel'kej miere ovplyvnuje aj priestorovú predstavivost' detí, čo chceme overit' v nami realizovanom výskume. Tvrdíme, že prvky virtuálnej reality počítačových hier sú prirodzeným prostredím pre dnešnú dospievajúcu generáciu.

Informačné a komunikačné technológie sa stali neodvratnou súčast'ou každodenného života človeka od jeho najmladšieho veku. Stretávame sa s nimi v každom odbore, výrobnom procese, pri zábave, športe. Výnimkou nie je ani vzdelávanie. „Pod slovom technológie označujeme technické prostriedky, postupy a zručnosti, ktoré sa používajú s určitým cielom a prinášajú praktické výsledky. Sú to technológie, ktoré súvisia so zberom, zaznamenávaním a výmenou informácií.“"(Martičenková, Tóblová, s.25)

Masívne rozširovanie aplikácii informačno-komunikačných technológií vo všetkých oblastiach spoločnosti, počnúc riadením, administratívou a službami, výrobnými technológiami, nevynímajúc ani šport a kultúru a teda ani vzdelanie, priamo ovplyvňuje vzdelávacie systémy. Ukazuje sa, že požiadavky na kvalitu vzdelávania, spojenú s neustále narastajúcimi požiadavkami na vedomosti a zručnosti absolventov škôl, nebude možné $\mathrm{v}$ budúcnosti dosiahnut' bez ciel’avedomej aplikácie informačno-komunikačných prostriedkov v celom systéme vzdelávania. Bude potrebné zmenit' nielen metódy výučby na všetkých vzdelávacích stupňoch, ale aj štátnu vzdelávaciu politiku. Zmena štátnej vzdelávacej politiky znamená uskutočnenie zásadnej školskej reformy. Ciel’om reformy musí byt' zosúladenie vzdelávacích cielov a postupov na ich dosiahnutie, so súčasnými požiadavkami spoločnosti a s požiadavkami súčasného vývoja spoločnosti a vedeckého poznania.

Sme svedkami toho, že dnešné deti dávajú prednost' obrazovkám počítačov, tabletom a herným konzolám pred hraním sa s kockami, autíčkami, bábikami alebo spoločenským či športovým aktivitám so svojimi rovesníkmi. V nami navrhnutom výskumnom projekte sme sa zamerali na zatial' neriešenú otázku vplyvu virtuálneho sveta počítačových hier na rozvoj priestorovej predstavivosti žiakov. Hladáme odpoved' na otázku, či dokáže virtuálny svet počítačových hier dostatočne nahradit úlohu reálnych predmetov didaktických pomôcok v oblasti priestorovej predstavivosti. Vo výskumnom projekte, v pedagogickom experimente, sú používané virtuálne modely a je sledovaný ich vplyv na rozvoj priestorovej predstavivosti žiakov. Výskumným cielom je upriamenie pozornosti spoločnosti na celospoločenskú nevyhnutnost' skúmania vplyvu počítačových hier, ako významného faktoru, ktorý pôsobí na celkový vývoj diet’ata. Zastávame názor, že výučba s použitím virtuálnych modelov dokáže, v istých prípadoch plne nahradit' skutočné predmety používané vo výučbe technických a prírodovedných predmetov. 
Použitie virtuálnych modelov je výhodné aj z ekonomického hladiska. Vytvorenie virtuálneho 3D modelu v elektronickej podobe je možné zrealizovat' s minimálnymi finančnými prostriedkami (sériová výroba, distribúcia) a vybavit’ nimi širokú škálu škôl.

\section{Výskumné ciele}

Ciel'om výskumného problému bolo zistit', či použitie virtuálnych 3D modelov vo výučbe je rovnocenné s použitím skutočných predmetov a či obe výučbové metódy majú rovnaký vplyv na rozvoj priestorovej predstavivosti žiakov vo vyučovacom procese. Na základe výsledkov výskumu posúdit či didaktické prostriedky prezentované systémami virtuálnej reality dokážu v dostatočnej miere nahradit' didaktické pomôcky prezentované skutočnými predmetmi, práve $\mathrm{v}$ nami sledovanej oblasti rozvoja priestorovej predstavivosti.

Z výskumného ciel’a boli určené výskumné úlohy, splnenie ktorých zaručuje dosiahnutie stanovených ciel'ov.

Pre potreby výskumu bolo nutné analyzovat' jednotlivé tematické celky v Štátnom vzdelávacom programe s ciel'om nájst' také témy, ktoré jednak úzko súvisia s rozvojom priestorovej a technickej predstavivosti a pri ktorých by bolo možné použitie virtuálnych 3D modelov, z pohl'adu zamerania výskumu, najvhodnejšie. To znamená, hladat' možnosti použitia virtuálnych 3D modelov v takých témach, kde ich vplyv na výučbu je výrazný a čo najlepšie meratel'ný.

Okrem úlohy analyzovania technického vzdelávania na základných školách a stanovenia vhodných tematických celkov pôsobiacich na rozvoj priestorovej predstavivosti žiakov, bolo potrebné riešit' aj d’alšie úlohy výskumného programu, ktoré súvisia s realizáciu pedagogického experimentu.

Jednou vel'mi dôležitou úlohou pri príprave pedagogického experimentu bola úloha návrhu a prípravy „didaktického balíčka“, ktorý okrem štandardných výučbových podkladov (prezentácie) zahrňoval aj vytvorenie virtuálnych 3D modelov, ako didaktickej pomôcky $\mathrm{k}$ výučbe. To si vyžiadalo urobit podrobnú analýzu dostupných softvérových prostriedkov pre tvorbu a prezentáciu virtuálnych modelov. Autormi bola vytvorená hodnotiaca metodika na posúdenie vhodnosti softvérového balíka na tvorbu a prezentáciu virtuálnych modelov. Táto metodika bola použitá pri analýze a výbere softvérových nástrojov $\mathrm{k}$ tvorbe virtuálnych $3 \mathrm{D}$ modelov. Výsledkom riešenia týchto technických otázok, vyplývajúcich zo stanovenej výskumnej úlohy, bolo vytvorenie kompaktného didaktického balíčka obsahujúceho nielen samotné virtuálne 3D modely, ale aj prezentačný systém a softvér pre tvorbu 3D modelov.

\section{Výskumné hypotézy}

Na zistenie do akej miery ovplyvňuje použitie virtuálnych modelov vo výučbe rozvoj priestorovej predstavivosti žiakov sme sa rozhodli využit' prirodzený pedagogický experiment. Metodika prirodzeného pedagogického experimentu predpokladá vytvorenie experimentálnej a kontrolnej vzorky (skupiny). V nami uskutočnenom experimente, v kontrolnej skupine bola výučba organizovaná s využívaním skutočných modelov a v experimentálnej skupine s podporou vytvorených virtuálnych 3D modelov. Nezávisle premennou v experimente bolo použitie rôznej učebnej pomôcky vo výučbe. V prípade kontrolnej skupiny, učebnou pomôckou boli skutočné modely a v prípade experimentálnej 
skupiny virtuálne 3D modely. Závisle premennou (pozorovaným znakom) u oboch skupín bola vedomostná úroveň respondentov (žiakov) z vybratého učiva - tematického celku.

Pre uvedený výskumný problém sme stanovili hlavnú hypotézu H1 nasledovne:

\section{H1: Respondenti experimentálnej skupiny po absolvovaní výučby s využitím virtuálnych 3D modelov dosiahnu rovnakú vedomostnú úroveň vo výstupnom teste $\mathrm{z}$ tematického celku zameraného na priestorovú predstavivost' ako respondenti kontrolnej skupiny.}

Na potvrdenie alebo zamietnutie hypotézy H1 bola použitá metóda štatistickej analýzy sumárnych výsledkov získaných vyhodnotením vedomostnej úrovne respondentov vo výstupnom teste.

Vo výučbe bol aplikovaný prezentačný systém virtuálnej reality, ktorého ovládanie bolo identické so systémami virtuálnej reality $\mathrm{v}$ počítačových hrách. Tým vo výučbe bolo vytvorené prostredie počítačovej virtuálnej reality, ktoré je súčasnou mladou generáciou aj plne akceptované. Takto bola pre výskumný tím vytvorená aj možnost', ubezpečit' sa v predpoklade, že žiaci toto prostredie vnímajú ako užívatel'sky vžité, ktoré je už súčastou ich každodenného života.

\section{Základný súbor a výber výskumnej vzorky}

\section{Výber základného súboru:}

K rozvoju priestorovej predstavivosti u detí dochádza v dvoch etapách. Prvé obdobie je v 5. a 6. roku života a druhé obdobie je medzi 10. až 14. rokom (Kuric, 1992). Prvé obdobie je predškolským obdobím, v ktorom je realizácia pedagogického experimentu komplikovaná. Jediným meratel’ným výstupom na posúdenie úrovne priestorovej predstavivosti u detí v tomto veku sú ich kresby. Systém analýzy detskej kresby by tak vyžadoval experiment so silným vedeckým zázemím v oblasti detskej psychológie. $\mathrm{Z}$ uvedeného dôvodu sa autori vo výskume sústredili na kategóriu detí vo veku medzi 10 . až 14. rokom. Deti v tomto období navštevujú druhý stupeň základných škôl. Majú viaceré vyučovacie predmety a témy, $\mathrm{v}$ ktorých sa predpokladá aplikácia priestorovej predstavivosti. Ďalším dôležitým faktorom v príprave experimentu bola skutočnost', že deti v tomto veku majú už väčšie skúsenosti s hraním počítačových hier, ktorých dej sa odohráva vo virtuálnom 3D prostredí, v porovnaní s det’mi vo veku 5-6 rokov. Uvedené skutočnosti zúžili výber základného súboru pre pedagogický experiment na tematické celky vo vyučovaní predmetov na základných školách. Konkrétne v ročníkoch 5 až 8 na druhom stupni ZŠ.

Základné školy v Slovenskej republike od 1. septembra 2015 vzdelávajú podl'a inovovaného Štátneho vzdelávacieho programu (ŠVP). Na základe analýzy štátneho vzdelávacieho programu ISCED 2, (https://www.minedu.sk/inovovany-svp-pre-zakladneskoly/a http://www.statpedu.sk/clanky/inovovany-statny-vzdelavaci-program/inovovanysvp-pre-2stupen-zs ) bolo rozhodnuté experiment uskutočnit' v rámci predmetu Technika v tematickom celku Grafická komunikácia. Na kreslenie technických náčrtov a výkresov je schopnost' aplikovania priestorovej predstavivosti klúčcová. Technický výkres, či náčrt môže byt' preto prvkom meratel'nosti, pre tak silno abstraktnú intelektuálnu schopnost', 
akou je priestorová predstavivost'. Považujeme ho za ideálny hodnotiaci element priestorovej predstavivosti respondentov pre účely pedagogického experimentu zameraného na posúdenie vplyvov súvisiacich s rozvojom priestorovej predstavivosti žiakov.

V tematickom celku Grafická komunikácia sa žiaci učia základy navrhovatel’skej činnosti, rozvíjajú svoje technické myslenie. Následne je vo výučbe venovaná pozornost' základom technickej komunikácie - zobrazovaniu, technický náčrt - kreslenie, technický výkres - čítanie. Kreslenie technických náčrtov sa preto môže stat' vyjadrením úrovne technickej a priestorovej predstavivosti žiaka, teda aj vplyvu virtuálnych $3 \mathrm{D}$ alebo reálnych modelov na rozvoj priestorovej predstavivosti žiakov vo výučbe.

Výber výučbovej témy ohraničil aj výber základného súboru a to na žiakov siedmeho ročníka základných škôl v SR.

\section{Výber a rozsah výskumnej vzorky:}

Výber a rozsah výskumnej vzorky pre pedagogický experiment bol ovplyvnený jeho organizačným zvládnutím a schopnostou zabezpečenia potrebného počtu reálnych súborov 3D modelov pre žiakov kontrolných skupín tak, aby žiaci mohli pracovat' samostatne. Dôležitým limitujúcim faktorom bola ochota škôl zapojit' sa do pedagogického experimentu. Nie všetky oslovené školy súhlasili $\mathrm{s}$ účastou v experimente. Okrem týchto požiadaviek, pri výbere bola uplatnená požiadavka, aby žiaci, ktorí vytvoria súbor respondentov boli zo školy, na ktorej sa vyučuje predmet Technika kvalifikovanými učitel’mi a škola bola vybavená počítačovou učebňou. Vytvorený experimentálny súbor respondentov splňujúci stanovené podmienky tvorilo 240 žiakov zo 14 tried. Experimentu sa zúčastnilo 6 škôl Nitrianskeho okresu a 6 škôl Topol'čianskeho okresu, v rámci Nitrianskeho samosprávneho kraja v Slovenskej republike.

\section{Použité štatistické metódy spracovania výsledkov výskumu}

Na potvrdenie platnosti stanovenej hypotézy v pedagogickom experimente boli použité štatistické metódy bežne aplikované v pedagogickom výskume. Závisle premennou (pozorovaným znakom) u oboch skupín bola dosiahnutá vedomostná úroveň respondentov v tematickom celku Grafická komunikácia. Na získanie informácií o vedomostnej úrovni žiakov bol vytvorený neštandardizovaný výstupný vedomostný test (Kunová, S. 2016).

Prvým krokom štatistického spracovania dát bolo vytvorenie štatistického súboru dát zo získaných výsledkov hodnotenia vedomostných testov. Štandardnou štatistickou metódou boli stanovené základné údaje popisnej štatistiky: štatistický súbor, diskrétne znaky, početnost', aritmetický priemer, medián, modus, variačné rozpätie, rozptyl a smerodajná odchýlka.

Druhým krokom bolo štatistické overovanie platnosti stanovených hypotéz. Ako prvé boli testované rovnosti rozptylov výsledkov dvoch štatistických súborov, experimentálnej a kontrolnej skupiny $\left(\sigma_{1}{ }^{2}, \sigma_{2}{ }^{2}\right)$.

Pre štatistické overenie rovnosti rozptylov dvoch nami sledovaných štatistických súborov bola stanovená nulová (pracovná) hypotéza $\mathrm{H}_{\mathrm{OD}}$. Testovacím kritériom bol pomer:

$$
F=\frac{S_{1}^{2}}{S_{2}^{2}}
$$


$S_{1}^{2}$ a $S_{2}^{2}$ sú výberové rozptyly jednotlivých výberových štatistických súborov.

Pre štatistické výpočty boli použité nástroje štatistickej analýzy v programe Excel. Platnost' hypotézy bola overovaná na hladine významnosti $\alpha=0,05$ (Markechová, Tirpáková, Stehlíková, 2011).

Uplatnením kriteriálneho pravidla $\mathrm{z}$ dvojvýberového F-testu pre rozptyl dostávame vzt'ah (v programe Excel):

$$
F<F_{k \frac{\alpha}{2}}(m-1, n-1)
$$

m - je rozsah súboru s väčším výberovým rozptylom

n - je rozsah súboru s menším výberovým rozptylom

$F_{k \frac{\alpha}{2}}$ - je kritická hodnota Fisherovho-Snedecorovho rozdelenia s $(k, l)$ stupňami vol'nosti.

Ak je hodnota testovacieho kritéria $\mathrm{F}$ menšia ako kritická hodnota FisherovhoSnedecorovho rozdelenia na hladine významnosti $\alpha=0,05$, tak prijímame nulovú (pracovnú) štatistickú hypotézu $H_{0 D}$ pre rovnost' rozptylov:

Oba testované štatistické súbory (experimentálna skupina, kontrolná skupina) vykazujú na hladine významnosti $\alpha=0,05$ rovnost' rozptylov $\sigma_{1}^{2}=\sigma_{2}^{2}$.

$\mathrm{V}$ opačnom prípade prijímame alternatívnu hypotézu o nerovnosti rozptylov $\mathrm{H}_{1 \mathrm{D}}: \sigma_{1}^{2} \neq$ $\sigma_{2}^{2}$ :

Oba testované štatistické súbory (experimentálna skupina, kontrolná skupina) vykazujú na hladine významnosti $\alpha=0,05$ nerovnost' rozptylov $\sigma_{1}^{2} \neq \sigma_{2}^{2}$ (Markechová, Tirpáková, Stehlíková, 2011).

Ďalším krokom štatistickej verifikácie hypotéz bolo testovanie rovnosti stredných hodnôt $\mu_{1}=\mu_{2}$ testovaných dvoch štatistických súborov (kontrolnej a experimentálnej skupiny). Potvrdenie tejto rovnosti by znamenalo, že rozdiely zaznamenané vo výsledkoch experimentálnej a kontrolnej skupiny sú štatisticky nevýznamné, čiže výsledky oboch skupín môžeme považovat' za rovnaké. Pre štatistické overenie rovnosti stredných hodnôt $\mu_{1}=\mu_{2}$ bola stanovená nulová (pracovná) hypotéza HosH.

$\mathrm{Na}$ základe predchádzajúceho testovania rovnosti rozptylov bol pri overovaní nulovej (pracovnej) hypotézy Hosh použitý t-test (Markechová, Tirpáková, Stehlíková, 2011). Na výpočet štatistických hodnôt boli použité nástroje štatistickej analýzy v programe Excel. Hypotéza bola potvrdzovaná na hladine významnosti $\alpha=0,05$.

\section{Pedagogický experiment}

Pedagogický experiment bol navrhnutý s ciel'om získat' relevantné údaje na overenie platnosti stanovenej výskumnej hypotézy. Pedagogický experiment bol realizovaný na šiestich základných školách Nitrianskeho a Topolčianskeho okresu. Spolu sa experimentu zúčastnilo 240 respondentov. 


\section{Časovo tematický plán pedagogického experimentu}

Časovo tematický plán pedagogického experimentu bol rozdelený do nasledovných tematických častí:

\section{- Prípravná fáza pedagogického experimentu}

- V prípravnej fáze boli navrhnuté a pre výučbu zabezpečené 3D reálne modely a 3D virtuálne modely. Bol navrhnutý vstupný a výstupný test a pripravené podkladové materiály $\mathrm{k}$ výučbe (výkladová prezentácia, metodické pokyny).

- Vstupné testovanie

- Vstupné testovanie - realizované anonymným vstupným testom, ktorého výsledky boli použité k vytvoreniu experimentálnej a kontrolnej skupiny.

- C̆asový rozsah testu: 1 vyučovacia hodina

- Výučbová čast' experimentu

- Výučbová čast' experimentu bola rozdelená na dve časti. Teoretickú, ktorá pozostávala z výkladu učiva a cvičenia, na ktorých žiaci aplikovali získané vedomosti pri riešení úloh.

- Časový rozsah teórie: 1 vyučovacia hodina

- Časový rozsah cvičení: 1 vyučovacia hodina

- Medzi hodinou teórie a cvičením bola vždy zaradená časová prestávka 1 týždeň.

- Výstupné testovanie

- Výstupné testovanie bolo realizované anonymným výstupným testom, ktorého výsledky boli použité $\mathrm{k}$ overovaniu platnosti výskumnej hypotézy.

- Časový rozsah testu: 1 vyučovacia hodina

\section{Návrh a vytvorenie virtuálnych $3 D$ modelov}

Pred samotnou konštrukciou virtuálnych/reálnych 3D modelov, bolo potrebné stanovit', aké konkrétne geometrické tvary budú na dosiahnutie vytýčených ciel’ov najvhodnejšie. Po diskusii v širšom kolektíve spolupracovníkov bolo vybratých 20 modelov, o ktorých sme predpokladali, že sú vhodné $\mathrm{k}$ aplikovaniu $\mathrm{v}$ experimente. $\mathrm{V}$ konečnej príprave experimentu, vzhl'adom na vel'ký počet respondentov a priestorové rozmiestnenie škôl, $\mathrm{v}$ kontrolnej skupine vo výučbe boli použité drevené modely $\mathrm{z}$ didaktickej stavebnice „Modely strojových súčiastok“, ktorú školy vlastnili v dostatočnom počte pre potreby experimentu. $Z$ tohto dôvodu boli virtuálne modely vytvorené podla drevených predlôh z použitej didaktickej stavebnice.

Virtuálne 3D modely boli vytvorené v programe CAD/CAM v systéme Geometric Design. Technologický postup tvorby virtuálnych telies v systéme Geomegic Design je silne ovplyvnený metódami strojového obrábania materiálov, pre ktoré bol tento CAM systém vyrobený. Výhodou programu Geomagic Design je tvorba technickej dokumentácie vytvoreného 3D telesa prostredníctvom automatického systému kreslenia, ktorý na základe definovaného modelu a stanovených parametrov výkresu vytvorí celú technickú dokumentáciu bez potreby zásahu užívatel’a. Vytvorené virtuálne 3D modely sú uvedené na obr. 1 

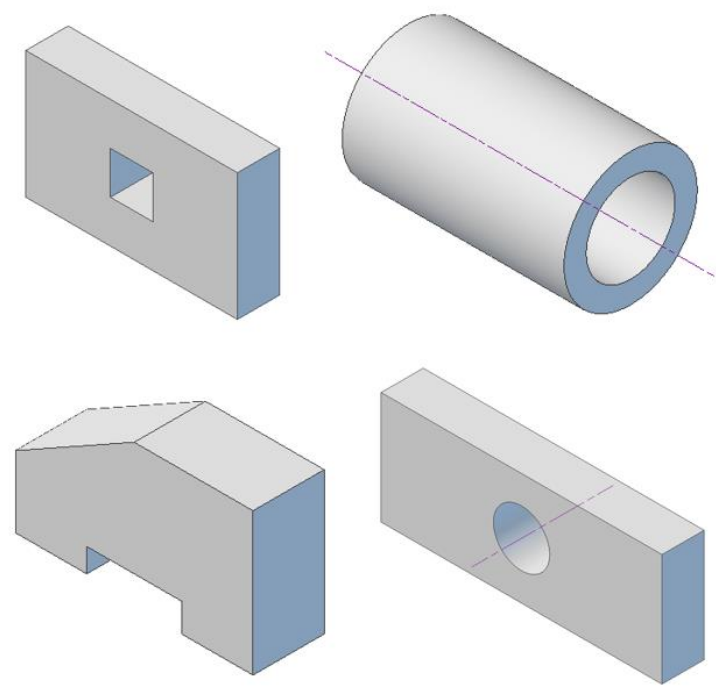

Obrázok 1: Tvary virtuálnych 3D modelov vyrobených pre účely výskumu

\section{Rozdelenie respondentov do skupín - vstupný test}

Jednou zo základných požiadaviek pedagogického experimentu je rozdelenie respondentov do dvoch skupín - experimentálnej a kontrolnej. Ideálnym prípadom rozdelenia by bolo uplatnenie metódy náhodného rozdelenia. Postup náhodného rozdelenia respondentov nemohol byt' uplatnený z organizačných dôvodov. Riaditelia škôl nedovolili rozdelit' žiakov do tried podl'a potrieb výskumu. Riešitel'mi muselo byt' akceptované už stanovené rozdelenie žiakov do jednotlivých tried. Preto rozdelenie do dvoch výkonovo rovnakých skupín bolo uskutočnené na základe výsledkov anonymného vstupného testu. Vstupný test bol zameraný na priestorovú predstavivost' žiakov.

\section{Vytvorenie experimentálnej a kontrolnej skupiny}

Pre experiment bolo k dispozící spolu 240 respondentov zo šiestich škôl Nitrianskeho samosprávneho kraja. Respondenti boli žiakmi 14 tried.

Snahou riešitel'ov bolo vytvorit' takú kombináciu rozdelenia tried do kontrolnej a experimentálnej skupiny, aby obe skupiny boli čo najvyrovnanejšie z pohl'adu počtu respondentov, priemeru a mediánu dosiahnutých výsledkov vstupného testu. Výsledné rozdelenie žiakov do experimentálnej a kontrolnej je uvedené v tabul'ke 1. 


\begin{tabular}{|c|c|c|c|c|c|c|}
\hline Skupina & Respondentov & Priemer & Medián & Min & Max & $\begin{array}{c}\text { Variačné } \\
\text { rozpätie }\end{array}$ \\
\hline \hline Kontrolná & 125 & 74 & 76 & 32 & 96 & 64 \\
\hline Experimentálna & 115 & 74 & 76 & 28 & 100 & 72 \\
\hline
\end{tabular}

Tabulka 1: Tabul'ka popisnej štatistiky pre vybratú kontrolnú a experimentálnu skupinu respondentov

\section{Výučba a testovanie}

Výučba a testovanie respondentov bolo rozložené do štyroch vyučovacích hodín v trvaní 45 minút $\mathrm{v}$ týždňových intervaloch. Každý týždeň bola $\mathrm{k}$ dispozícii len jedna vyučovacia hodina. Celý proces experimentu tak trval v každej triede spolu 4 týždne. Organizácia bola nasledovná:

1. Vstupný test

- Materiálno technické zabezpečenie: písacie potreby, vstupný test.

- Priebeh vyučovacej hodiny:

- rozdanie písacích potrieb a vstupného testu

- pokyny $\mathrm{k}$ vypíñaniu testu

- $\quad$ vypracovanie testov (40 min.)

- Výstup: vypracované vstupné testy

2. Teória

- Materiálno technické zabezpečenie: učebňa s projektorom, prezentácia vyučovacej hodiny (použitý - Didaktický balíček - prezentácia výkladu), skutočné alebo virtuálne modely.

- Priebeh vyučovacej hodiny:

- Prezentačný výklad učiva (použitý Didaktický balíček - prezentácia výkladu)

- Ukážka tvorby nákresu pravouhlého zobrazovania pomocou virtuálneho / skutočného modelu č. 1

Poznámka: Náčrt kreslí učitel'. Žiaci sledujú virtuálny/skutočný predmet na projektore/v rukách učitel’a. Prekresl'ujú nákres z tabule do svojich zošitov.

Poznámka: V prípade virtuálnych modelov učitel' nekomentuje žiakom ovládanie virtuálneho prostredia.

- Výstup: realizovaný výklad učiva

3. Cvičenie

- Materiálno technické zabezpečenie: počítačová učebňa (pre experimentálnu skupinu), virtuálne / skutočné modely, pozorovací hárok. Poznámka: Každý žiak musí mat' $\mathrm{k}$ dispozícii vlastný skutočný/virtuálny model. Žiaci musia pracovat' samostatne.

- Priebeh vyučovacej hodiny:

- Krátke opakovanie z predchádzajúcej hodiny 
- Opätovné kreslenie modelu č. 1 na tabulu (opakovanie)

- Samostatná práca žiakov pri kreslení pripravených modelov skutočných/virtuálnych

- Vyhodnotenie samostatnej práce žiakov

Poznámka: Pri samostatnej práci žiakov v experimentálnej skupine učitel' sleduje, či žiaci dokážu pracovat' s virtuálnym prostredím. $\mathrm{V}$ prípade, že niektorí respondenti potrebujú pomôct' pri práci $\mathrm{s}$ virtuálnym prostredím učitel' ho primerane inštruuje.

4. Výstupný test

- Materiálno technické zabezpečenie: výstupný test, počítačová učebňa (pre experimentálnu skupinu), virtuálne / skutočné modely, pozorovací hárok. Poznámka: Každý žiak musí mat' $\mathrm{k}$ dispozícii vlastný skutočný/virtuálny model. Žiaci musia pracovat' samostatne

- Priebeh vyučovacej hodiny:

- $\quad$ rozdanie písacích potrieb a výstupného testu

- pokyny k vypĺňaniu testu

- $\quad$ vypracovanie testov (40 min.)

- Výstup: vypracované výstupné testy

\section{Výstupný vedomostný test}

Použitý výstupný vedomostný test $\mathrm{v}$ experimente bol zameraný na overenie vedomostí respondentov výskumu v tematickom celku grafická komunikácia. Analýza poznatkov z odbornej literatúry s problematikou rozvoja priestorovej predstavivosti žiakov ukázala, že pre účely vedomostného testovania žiakov v tejto oblasti nie je doposial' vypracovaný a teda ani dostupný žiadny štandardizovaný vedomostný test. Autori sa preto rozhodli pristúpit' k tvorbe vlastného testu.

Podl'a špecifických ciel’ov Niemerkovej taxonómie bola vytvorená pre každú zo štyroch úrovní jedna úlohu na overenie stanovených vzdelávacích cielov. Každá úloha je tvorená čiastkovými „podúlohami - otázkami“, ktoré sú označené písmenami A-E. Pri výbere konkrétnych položiek výstupného vedomostného testu bolo snahou riešitel'ov vytvorit' úlohu v položke tak, aby riešenie vyžadovalo od žiaka (respondenta) uplatnenie priestorovej predstavivosti. Ciel'om riešitel’ov pri konštrukcii a formulovaní jednotlivých úloh a podúloh výstupného testu bolo vytvorenie vhodného nástroja na čo najväčšiu možnú mieru a objektivitu meratel’nosti tak silne kvalitatívnej zložky akou je priestorová predstavivost' (Kunová, S. 2016).

Definovanie konkrétnych vzdelávacích ciel'ov uskutočnenej výučby v experimente pre vybraný tematický celok „Grafická komunikácia“ a ich zaradenie do taxonometrických úrovní je vyjadrený v Tabul'ke 2 . 


\begin{tabular}{|c|c|}
\hline $\begin{array}{l}\text { Č.Ú. } \\
\text { N.T. }{ }^{1}\end{array}$ & Definície špecifických ciel’ov výchovnovzdelávacieho procesu \\
\hline 1. & $\begin{array}{l}\text { Žiak pozná definície základných pojmov technického kreslenia. (pravouhlé } \\
\text { premietanie, nárys, bokorys, pôdorys, typy čiar ...) }\end{array}$ \\
\hline 2. & $\begin{array}{l}\text { Žiak vlastnými slovami interpretuje význam a použitie rôznych typov čiar } \\
\mathrm{v} \text { technickom kreslení. }\end{array}$ \\
\hline 3. & $\begin{array}{l}\text { Žiak aplikuje teoretické poznatky z oblasti technického kreslenia kreslením } \\
\text { technických náčrtov (nárys, bokorys, pôdorys) predložených virtuálnych } \\
\text { alebo skutočných 3D modelov. }\end{array}$ \\
\hline 4. & $\begin{array}{l}\text { a) Žiak rieši problémovú úlohu kreslením technického náčrtu predmetu, } \\
\text { ktorý si vybavuje len vo svojej mysli. } \\
\text { b) Žiak dokáže na základe predložených technických nákresov predmetu } \\
\text { (nárys, bokorys, pôdorys) vymodelovat' jeho tvar pomocou } \\
\text { modelovacej hmoty. }\end{array}$ \\
\hline
\end{tabular}

Tabul'ka 2: Taxonómia vzdelávacích ciel'ov upravená podl’a Inovovaného ŠVP (Štátneho vzdelávacieho programu) pre 2. stupeň ZŠ (www.statpedu.sk)

\section{Výsledky výskumu a diskusia}

$\mathrm{Na}$ overenie hypotézy H1 boli využité získane výsledky z odpovedí respondentov (riešenia úloh) na vytvorený neštandardizovaný výstupný vedomostný test, ktorého znenie bolo rovnaké pre experimentálnu aj kontrolnú skupinu. Jediný rozdiel spočíval v materiálnom zabezpečení konkrétnej úlohy č. 3 - Vytvorit' náčrty pravouhlého zobrazenia pre zadaný model. Experimentálna skupina mala $\mathrm{k}$ dispozícii virtuálny $3 \mathrm{D}$ model a kontrolná skupina skutočný model. Tvarovo boli oba modely rovnaké. Test pozostával zo štyroch úloh zameraných na jednotlivé taxonomické vzdelávacie ciele Niemerkovej taxonómie.

Pri zostavovaní podrobnej štatistiky pre účely potvrdenia platnosti hypotézu H1 sme najprv určili diskrétne znaky štatistického súboru (Tabul'ka 3: Diskrétne znaky štatistického súboru )

\begin{tabular}{|c|c|c|c|c|c|c|}
\hline \multirow{2}{*}{ Názov diskrétneho znaku štatistického súboru } & \multicolumn{5}{|c|}{ Úlohy výstupného testu } \\
\cline { 3 - 8 } & $\mathbf{1}$ & $\mathbf{2}$ & $\mathbf{3}$ & $\mathbf{4}$ & Sumár \\
\hline \multicolumn{2}{|c|}{ Maximálny možný počet bodov } & 5 & 5 & 9 & 16 & 35 \\
\hline \multirow{2}{*}{$\begin{array}{c}\text { Kontrolná skupina } \\
\text { Min. získaný počet bodov }\end{array}$} & 2,5 & 2 & 0 & 4 & 12,5 \\
\cline { 2 - 7 } & Max. získaný počet bodov & 5 & 5 & 9 & 13 & 32 \\
\hline $\begin{array}{c}\text { Experimentálna } \\
\text { skupina }\end{array}$ & Min. získaný počet bodov & 2,5 & 1,5 & 2,5 & 4 & 13,5 \\
\cline { 2 - 8 } & Max. získaný počet bodov & 5 & 5 & 9 & 13 & 32 \\
\hline
\end{tabular}

Tabul'ka 3: Diskrétne znaky štatistického súboru

${ }^{1}$ Číslo úrovne podl’a Niemierkovej taxonómie vzdelávacích cielov 
Následne boli výsledky vedomostného testu upravené do tabul'kovej a grafickej podoby pre jednotlivé úlohy výstupného testu ako aj pre jeho celkové sumárne výsledky. V príspevku uvádzame sumárne výsledky, ktoré boli použité pri štatistickom potvrdení hypotézy.

\section{Rozdelenie absolútnej početnosti - Sumár}

15

10

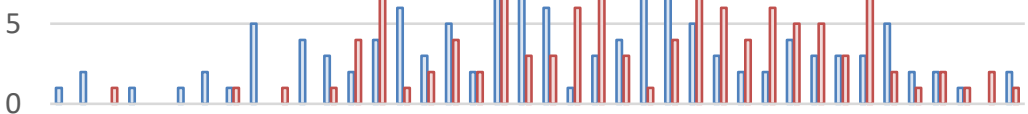

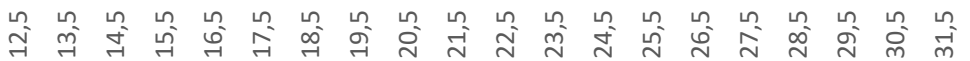

Kontrolná skupina

Experimentálna skupina

Graf 1: Graf rozdelenia absolútnej početnosti pre sumárne výsledky

\begin{tabular}{|c|c|c|c|c|c|c|c|c|c|c|}
\hline \multirow{2}{*}{$\begin{array}{c}\text { Urovne } \\
\text { znaku }\end{array}$} & \multicolumn{2}{|c|}{$\begin{array}{c}\text { Absolútna } \\
\text { početnost }\end{array}$} & \multicolumn{2}{|c|}{$\begin{array}{c}\text { Kumulatívna } \\
\text { početnost' }\end{array}$} & \multicolumn{2}{c|}{$\begin{array}{c}\text { Relatívna } \\
\text { početnost' }\end{array}$} & \multicolumn{2}{c|}{$\begin{array}{c}\text { Kum. relatívna } \\
\text { početnost }\end{array}$} & \multicolumn{2}{c|}{$\begin{array}{c}\text { Relatívna } \\
\text { početnost' v [\%] }\end{array}$} \\
\cline { 2 - 11 } & KS & ES & KS & ES & KS & ES & KS & ES & KS & ES \\
\hline 12,5 & 1 & 0 & 1 & 0 & 0,01 & 0,00 & 0,01 & 0,00 & $1 \%$ & $0 \%$ \\
\hline 13 & 2 & 0 & 3 & 0 & 0,02 & 0,00 & 0,02 & 0,00 & $2 \%$ & $0 \%$ \\
\hline 13,5 & 0 & 1 & 3 & 1 & 0,00 & 0,01 & 0,02 & 0,01 & $0 \%$ & $1 \%$ \\
\hline 14 & 1 & 0 & 4 & 1 & 0,01 & 0,00 & 0,03 & 0,01 & $1 \%$ & $0 \%$ \\
\hline 14,5 & 0 & 0 & 4 & 1 & 0,00 & 0,00 & 0,03 & 0,01 & $0 \%$ & $0 \%$ \\
\hline 15 & 1 & 0 & 5 & 1 & 0,01 & 0,00 & 0,04 & 0,01 & $1 \%$ & $0 \%$ \\
\hline 15,5 & 2 & 0 & 7 & 1 & 0,02 & 0,00 & 0,06 & 0,01 & $2 \%$ & $0 \%$ \\
\hline 16 & 1 & 1 & 8 & 2 & 0,01 & 0,01 & 0,06 & 0,02 & $1 \%$ & $1 \%$ \\
\hline 16,5 & 5 & 0 & 13 & 2 & 0,04 & 0,00 & 0,10 & 0,02 & $4 \%$ & $0 \%$ \\
\hline 17 & 0 & 1 & 13 & 3 & 0,00 & 0,01 & 0,10 & 0,03 & $0 \%$ & $1 \%$ \\
\hline 17,5 & 4 & 0 & 17 & 3 & 0,03 & 0,00 & 0,14 & 0,03 & $3 \%$ & $0 \%$ \\
\hline 18 & 3 & 1 & 20 & 4 & 0,02 & 0,01 & 0,16 & 0,03 & $2 \%$ & $1 \%$ \\
\hline 18,5 & 2 & 4 & 22 & 8 & 0,02 & 0,03 & 0,18 & 0,07 & $2 \%$ & $3 \%$ \\
\hline 19 & 4 & 7 & 26 & 15 & 0,03 & 0,06 & 0,21 & 0,13 & $3 \%$ & $6 \%$ \\
\hline 19,5 & 6 & 1 & 32 & 16 & 0,05 & 0,01 & 0,26 & 0,14 & $5 \%$ & $1 \%$ \\
\hline 20 & 3 & 2 & 35 & 18 & 0,02 & 0,02 & 0,28 & 0,16 & $2 \%$ & $2 \%$ \\
\hline 20,5 & 5 & 4 & 40 & 22 & 0,04 & 0,03 & 0,32 & 0,19 & $4 \%$ & $3 \%$ \\
\hline 21 & 2 & 2 & 42 & 24 & 0,02 & 0,02 & 0,34 & 0,21 & $2 \%$ & $2 \%$ \\
\hline 21,5 & 8 & 8 & 50 & 32 & 0,06 & 0,07 & 0,40 & 0,28 & $6 \%$ & $7 \%$ \\
\hline 22 & 8 & 3 & 58 & 35 & 0,06 & 0,03 & 0,46 & 0,30 & $6 \%$ & $3 \%$ \\
\hline 22,5 & 6 & 3 & 64 & 38 & 0,05 & 0,03 & 0,51 & 0,33 & $5 \%$ & $3 \%$ \\
\hline 23 & 1 & 6 & 65 & 44 & 0,01 & 0,05 & 0,52 & 0,38 & $1 \%$ & $5 \%$ \\
\hline
\end{tabular}




\begin{tabular}{|c|c|c|c|c|c|c|c|c|c|c|}
\hline 23 & 1 & 6 & 65 & 44 & 0,01 & 0,05 & 0,52 & 0,38 & $1 \%$ & $5 \%$ \\
\hline 23,5 & 3 & 7 & 68 & 51 & 0,02 & 0,06 & 0,54 & 0,44 & $2 \%$ & $6 \%$ \\
\hline 24 & 4 & 3 & 72 & 54 & 0,03 & 0,03 & 0,58 & 0,47 & $3 \%$ & $3 \%$ \\
\hline 24,5 & 7 & 1 & 79 & 55 & 0,06 & 0,01 & 0,63 & 0,48 & $6 \%$ & $1 \%$ \\
\hline 25 & 9 & 4 & 88 & 59 & 0,07 & 0,03 & 0,70 & 0,51 & $7 \%$ & $3 \%$ \\
\hline 25,5 & 5 & 11 & 93 & 70 & 0,04 & 0,10 & 0,74 & 0,61 & $4 \%$ & $10 \%$ \\
\hline 26 & 3 & 6 & 96 & 76 & 0,02 & 0,05 & 0,77 & 0,66 & $2 \%$ & $5 \%$ \\
\hline 26,5 & 2 & 4 & 98 & 80 & 0,02 & 0,03 & 0,78 & 0,70 & $2 \%$ & $3 \%$ \\
\hline 27 & 2 & 6 & 100 & 86 & 0,02 & 0,05 & 0,80 & 0,75 & $2 \%$ & $5 \%$ \\
\hline 27,5 & 4 & 5 & 104 & 91 & 0,03 & 0,04 & 0,83 & 0,79 & $3 \%$ & $4 \%$ \\
\hline 28 & 3 & 5 & 107 & 96 & 0,02 & 0,04 & 0,86 & 0,83 & $2 \%$ & $4 \%$ \\
\hline 28,5 & 3 & 3 & 110 & 99 & 0,02 & 0,03 & 0,88 & 0,86 & $2 \%$ & $3 \%$ \\
\hline 29 & 3 & 7 & 113 & 106 & 0,02 & 0,06 & 0,90 & 0,92 & $2 \%$ & $6 \%$ \\
\hline 29,5 & 5 & 2 & 118 & 108 & 0,04 & 0,02 & 0,94 & 0,94 & $4 \%$ & $2 \%$ \\
\hline 30 & 2 & 1 & 120 & 109 & 0,02 & 0,01 & 0,96 & 0,95 & $2 \%$ & $1 \%$ \\
\hline 30,5 & 2 & 2 & 122 & 111 & 0,02 & 0,02 & 0,98 & 0,97 & $2 \%$ & $2 \%$ \\
\hline 31 & 1 & 1 & 123 & 112 & 0,01 & 0,01 & 0,98 & 0,97 & $1 \%$ & $1 \%$ \\
\hline 31,5 & 0 & 2 & 123 & 114 & 0,00 & 0,02 & 0,98 & 0,99 & $0 \%$ & $2 \%$ \\
\hline 32 & 2 & 1 & 125 & 115 & 0,02 & 0,01 & 1,00 & 1,00 & $2 \%$ & $1 \%$ \\
\hline Spolu: & 125 & 115 & $\mathrm{x}$ & $\mathrm{x}$ & 1,00 & 1,00 & $\mathrm{x}$ & $\mathrm{x}$ & $100 \%$ & $100 \%$ \\
\hline
\end{tabular}

Tabul'ka 4: Tabul'ka početností pre sumárne výsledky všetkých štyroch úloh (Kunová,S.2016)

Súhrnné výsledky ukazovatel'ov popisnej štatistiky: aritmetický priemer, medián, modus, variačné rozpätie, rozptyl a smerodajná odchýlka sú uvedené v Tabul'ke 5 - Komplexná tabul'ka popisnej štatistiky.

\begin{tabular}{|c|c|c|c|c|c|c|c|c|c|c|}
\hline \multirow{3}{*}{$\begin{array}{c}\text { Ukazovatel } \\
\text { popisnej } \\
\text { štatistiky }\end{array}$} & \multicolumn{10}{|c|}{$\begin{array}{l}\text { Výsledky úloh výstupného testu } \\
\text { pre kontrolnú a experimentálnu skupinu }\end{array}$} \\
\hline & \multicolumn{2}{|c|}{1} & \multicolumn{2}{|c|}{2} & \multicolumn{2}{|c|}{3} & \multicolumn{2}{|c|}{4} & \multicolumn{2}{|c|}{ Spolu } \\
\hline & KS & ES & KS & ES & KS & ES & KS & ES & KS & ES \\
\hline $\begin{array}{c}\text { Aritmetický } \\
\text { priemer }\end{array}$ & 4,2 & 4,42 & 4,17 & 4,2 & 6,28 & 6,7 & 8,23 & 9,08 & 22,94 & 24,4 \\
\hline Medián & 4,5 & 4,5 & 4,5 & 4,5 & 6 & 7 & 7,5 & 9,5 & 22,5 & 25 \\
\hline Modus & 5 & 4,5 & 5 & 5 & 9 & 9 & 4,5 & 7 & 25 & 25,5 \\
\hline $\begin{array}{l}\text { Variačné } \\
\text { rozpätie }\end{array}$ & 2,5 & 2,5 & 3 & 3,5 & 9 & 6,5 & 9 & 9 & 19,5 & 18,5 \\
\hline Rozptyl & 0,4 & 0,37 & 0,82 & 0,63 & 4,08 & 3,49 & 8,27 & 6,49 & 19,75 & 14,3 \\
\hline $\begin{array}{l}\text { Smerodajná } \\
\text { odchýlka }\end{array}$ & 0,6 & 0,6 & 0,9 & 0,8 & 2,02 & 1,87 & 2,88 & 2,55 & 4,44 & 3,79 \\
\hline
\end{tabular}

Tabul'ka 5: Komplexná tabul'ka popisnej štatistiky 


\section{Štatistická verifikácia hypotézy $\mathrm{H1}$}

Pre verifikáciu platnosti hypotézy $\mathrm{H} 1$ boli použité nástroje štatistickej analýzy „Dvojvýberový F-test pre rozptyl“ a „Dvojvýberový t-test s nerovnostou rozptylov“ v programe Excel. Štatistickou analýzou komplexných výstupov z hodnotenia výsledkov didaktických testov bola platnost' hypotézy H1 zamietnutá.

\section{Hypotéza H1:}

Respondenti experimentálnej skupiny po absolvovani výučby s využitím virtuálnych $3 D$ modelov dosiahnu rovnakú vedomostnú úroveň vo výstupnom teste z tematického celku zameraného na priestorovú predstavivost' ako respondenti kontrolnej skupiny.

Výsledok štatistickej analýzy:

Štatistickou analýzou bolo potvrdené zamietnutie platnosti hypotézy H1 o dosiahnutí rovnakej vedomostnej úrovne experimentálnej a kontrolnej skupiny pre sumárne výsledky výstupného testu.

\section{Vyhodnotenie výsledkov výskumu}

Na základe výsledkov popisnej štatistiky) riešitelia pristúpili $\mathrm{k}$ javovej analýze podl’a Niemerkovej taxonómie vzdelávacích ciel'ov. Podl'a údajov tabul'ky 5 , vidiet', že celkové lepšie sumárne výsledky z výstupného testu dosiahli respondenti experimentálnej skupiny v pomere aritmetického priemeru 24,4 : 22,94 bodov. Celkový možný počet získaných bodov z výstupného testu bol 35 bodov. Kritickú hranicu osvojenia učiva bola stanovená podla Arbitrárneho postupu, ktorý je použivaný pri vedomostných testoch. Za predpokladu, že vo vedomostnom teste je zahrnuté len dôležité a reprezentatívne učivo, čo bolo v prípade experimentu splnené, potom kritická hodnota osvojenia učiva je na hranici $60 \%$-nej úspešnosti v teste (Turek, 1995, s.56). Prepočítaním na body je to 21 bodov.

V tabul'ke početností pre sumárne výsledky (Tabul'ka 4: Sumárna tabul'ka početností pre sumárne výsledky všetkých štyroch úloh) vidíme, že kritickú hranicu osvojenia si učiva neprekročilo v experimentálnej skupine 22 respondentov a v kontrolnej skupine až 40 respondentov. Spolu je to 62 respondentov, čo je 26 percent z celkového množstva zúčastnených respondentov vo výskume. Žiaden respondent nezískal plný počet bodov. Najlepšie bodové skóre bolo 32 bodov. V experimentálnej skupine takýto výsledok dosiahol jeden respondent, $v$ kontrolnej skupine dvaja respondenti. Najsilnejšia početnost' bola v kontrolnej skupine pre skóre 25 bodov a v experimentálnej skupine 25,5 bodu. Č́selné porovnávanie celkových výsledkov môže byt' skreslujúce, pretože neodzrkadluje štatistickú významnost' rozdielu v dosiahnutých výsledkoch oboch skupín. Preto boli závery spresnené štatistickou verifikáciou príslušnej hypotézy H1. Výsledkom štatistického spresnenia bolo zamietnutie hypotézy H1 na základe sumárnych výsledkov. To znamená, že poǔ̌itie dvoch výučbových metód vo vyučovaní (skutočné / virtuálne modely) nie je rovnocenné, t.j. tieto dve metódy nemajú rovnaký vplyv na rozvoj priestorovej predstavivosti žiakov vo vyučovacom procese. Žiaci, ktorí boli vyučovaní s použitím virtuálnych modelov v celkovom hodnotení dosiahli lepšie výsledky v porovnaní so žiakmi, ktorí vo vyučovaní použivali reálne modely.

Prvotným problémom výskumného projektu bolo hl'adanie odpovede na otázku, či použitie virtuálnych $3 \mathrm{D}$ modelov vo výučbe, v porovnaní s použitím skutočných modelov, môže 
mat' nepriaznivý, negatívny vplyv na rozvoj priestorovej predstavivosti žiakov. Podla vykonanej analýzy výsledkov z testov a z výsledkov štatistickej verifikácie hypotézy H1 tvrdíme, že použitie virtuálnych 3D modelov vo výučbe podporuje rozvoj priestorovej predstavivosti žiakov.

Výsledky výskumu potvrdili, že žiaci vykazujú nízku úroveň priestorovej predstavivosti. Na zistenie a objasnenie príčiny tohto závažného tvrdenia bol navrhnutý a realizovaný výskumný projekt analýzy výsledkov výstupného testu vo vztahu $\mathrm{k}$ jednotlivým jeho úlohám, ktoré boli koncipované podl'a Niemerkovej taxonómie vzdelávacích ciel’ov (Kunová, 2016). Výsledky analýzy tohto zámeru budú predmetom osobitného príspevku.

\section{Záver}

Hlavným výskumným problémom navrhnutého projektu bolo preukázanie, že použitie dvoch výučbových metód vo vyučovaní (skutočné / virtuálne modely) nie je rovnocenné, t.j. tieto dve metódy nemajú rovnaký vplyv na rozvoj priestorovej predstavivosti žiakov vo vyučovacom procese. Výskum preukázal, že žiaci, ktorí boli vyučovaní s použitím virtuálnych modelov v celkovom hodnotení dosiahli lepšie výsledky v porovnaní so žiakmi, ktorí vo vyučovaní používali reálne modely.

Výskum potvrdil pozitívny vplyv použitia virtuálnych 3D modelov vo výučbe na rozvoj priestorovej predstavivosti žiakov. Čo znamená, že aplikovanie systému virtuálnej reality vo výučbe technických a prírodovedných predmetov je vhodným prostriedkom na podporu a rozvoj kreatívnych predispozícií žiakov. Výsledky výskumu potvrdili však aj nízku úroveň priestorovej predstavivosti žiakov základných škôl.

Nedostatok finančných prostriedkov na obnovu didaktických pomôcok je možné do istej mieri kompenzovat' používaním systémov virtuálnej reality vo vyučovacom procese. Priebeh výskumu v experimentálnej skupine žiakov, v ktorej žiaci pracovali s virtuálnymi modelmi ukázal, že žiaci nemali problémy s ovládaním prezentačných systémov virtuálnej reality. Tento poznatok vedie autorov ku konštatovaniu, že hranie počítačových hier zanecháva u detí prirodzené užívatel'ské vedomosti a zručnosti, ktoré sú potom neskôr využitel'né aj vo výučbovom procese. Zabezpečenie prezentačného nástroja pre virtuálne modely v podobe inštalovania bežne a vol’ne dostupného softvéru Adobe Acrobat Readeru nevyžaduje žiadne investície a ani odborný technický personál. Je preto výhodný pre použitie vo výučbe na $Z \check{S}$.

Predpokladáme, že výsledky publikovaného výskumu budú zaujímavé nielen pre učitel'ov z praxe, ale oslovia aj širšiu odbornú verejnost' a stanú sa podnetom pre návrh a realizáciu cielených výskumov $\mathrm{v}$ tejto problémovej oblasti. Tento zámer sledovali autori pri svojom rozhodnutí podrobnejšie zverejnit' $\mathrm{v}$ príspevku metodický postupu, ktorý bol použitý vo výskume.

Pod'akovanie: Autori príspevku vyjadrujú pod’akovanie Katedre techniky a informačných technológií PF UKF v Nitre za podporu pri riešení výskumného projektu. 


\section{Literatúra}

ATKINSON, R. L. (2003). Psychológie. Praha: Portál, 2003. 751 s.

BEISETZER, P. - VRŠKOVÝ, R. (2008). Technická výchova v reflexii rozvoja priestorovej predstavivosti.In: IV. InEduTech 2008. Prešov: FHPV PU, 2008. s.106-109.

BURDEA, G. - COIFFET, P. (2003). Virtual Reality Technology 2nd ed. A WileyInterscience publication Canada 2003. $451 \mathrm{~s}$.

FAJNOROVÁ, E. (2012). Grafické zručnosti žiakov základných škôl v predmete Technika. In: Sborník příspěvků z mezinárodní studentské odborné konference. Západočeská univerzita Plzeň, 2012. s.21.

FLORKOVÁ, M. (2005). Rozvoj priestorovej predstavivosti na hodinách geometrie v 1 . ročníku ZŠ. Smolenice, 2005. http://pdfweb.truni.sk/zbornik/smolenice/smolkova.pdf.

GABAJOVÁ, M. (2010). Rozvíjanie priestorovej predstavivosti. In: Študentská vedecká konferencia FMFI UK. Bratislava: FMFI UK, 2010. s. 370-377.

HANDE, W. (1985). Gestaltung schöpferisch-technischer Schülertätigkeiten bein Experimentieren. In: Eksperymenty uczniow W nauczaniu techniki. Zielona Gora. 1985.

ILJINOVÁ, T. A. (1972). Pedagogika : Učebnice pro posluchače pedagogických institutů, 1. vyd. - Praha : SPN, 1972. - 600 s.

Inovovaný štátny vzdelávací program pre základné školy [online]: https://www.minedu.sk/inovovany-svp-pre-zakladne-skoly/

Inovovaný ŠVP pre 2. stupeň ZŠ [online]: http://www.statpedu.sk/clanky/inovovanystatny-vzdelavaci-program/inovovany-svp-pre-2stupen-zs

JIROTKOVÁ, D. (1990). Rozvoj prostorové predstavivosti žáků. In: Komenský, č. 5, Praha, 1990.

KELNAROVÁ, J. - MATĚJKOVÁ, E. (2010). Psychologie 1. díl, Pro studenty zdravotnických obori̊. Praha: Grada, 2010.

KUNOVÁ, S. (2016). Virtuálne 3D modely rozvíjajúce priestorovú predstavivost’ žiakov Základných škôl. Dizertačná práca. 2016, Pedagogická fakulta UKF v Nitre

KOŽUCHOVÁ, M. (1995). Rozvoj technickej tvorivosti. Bratislava: UK, 1995. $156 \mathrm{~s}$.

KURIC, J. (1992). Vývinová psychológia. Nitra: VŠPg, 1992. $115 \mathrm{~s}$.

MARKECHOVÁ, D. - TIRPÁKOVÁ, A. - STEHLÍKOVÁ, B. (2011). Základy štatistiky pre pedagógov. Edícia: Prírodovedec č. 458, UKF v Nitre, 2011. 405s.

MARTINČEKOVÁ, I. - TÓBLOVÁ, E. (2013). Didaktika odborného výcviku. Bratislava: Metodicko-pedagogické centrum, 2013, 67 s.

MOLNÁR, J. (2004). Rozvíjení prostorové představivosti (nejen) v stereometrii. Olomouc: UP, Katedra algebry a geometrie Př́rodovedecké fakulty, 2004.

MOLNÁR, J. - TLÁSKAL, J. (2012). Prostorová představivost nejen v matematice. http://www.phil.muni.cz/linguistica/art/molnar-tlaskal/mot-001.pdf (19.4.2013)

PAVELOVÁ, E. (2003). Priestorová predstavivost' a vyučovanie. In: Zborník Letná škola z teórie vyučovania matematiky PYTAGORAS 2003. s.78-82.

PERENČAJ, J. - REPÁŠ, V. (1985). Diagnostika rozvoja stereometrických predstáv študentov vysokých škôl technických. MFvŠ 16/4 s. 277-280.

StatSoft, Inc. Electronic Statistics Textbook. Tulsa, OK: StatSoft. [online]: http://www.statsoft.com/textbook/stathome.html (1999).

ŠAROUNOVÁ, A. (1988). Rozvijení geometrické predstavivosti ve škole. In MaFveŠ, Praha: SNP, roč.18 
Štátny vzdelávací program pre 2. stupeň základnej školy v Slovenskej republike. [online]: http://www.statpedu.sk/files/documents/svp/2stzs/isced2/isced2_spu_uprava.pdf (18.05.2013)

Štátny vzdelávací program. [online]: http://www.statpedu.sk/sk/Statny-vzdelavaciprogram.alej (18.05.2013)

TOMKOVÁ, V. (2012). Význam priestorovej predstavivosti v technickom vzdelávaní. Edukacja - Technika - Informatyka, issue: 1 / 2012 . CEEOL pdf, s.279-284. ( 20.4.2013) TOMKOVÁ, V. (2013). Technická neverbálna komunikácia. Nitra: PF UKF, 2013. s. 204. UHERČÍKOVÁ, V. (1999). Rozvíjanie priestorovej predstavivosti prostredníctvom hier a hračiek. In: Zborník z odborného seminára: Hra a hračka. Bratislava, Iuventa 1999. VITÁRIUŠOVÁ E. a kol. (2009). Pediatria pre prax v roku 10/2009. 